\title{
PELATIHAN POLA ASUH DEMOKRATIS ORANGTUA TERHADAP PENGETAHUAN, SIKAP DAN PERILAKU BEBAS NARKOBA
}

\author{
Grido Handoko Sriyono*, Yosef Wijoyo \\ Program Studi Magister Farmasi, Fakultas Farmasi, Universitas Sanata Dharma, Yogyakarta, Indonesia \\ email: gridoprob@gmail.com
}

\begin{abstract}
Abstrak
Peredaran gelap dan penyalahgunaan narkoba sudah masuk di semua lapisan masyarakat bahkan sampai di kalangan remaja, kondisi ini sangat memprihatinkan dan perlu upaya pencegahan secara serius dan berkelanjutan. Penelitian ini bertujuan untuk mengkaji efektivitas pelatihan pola asuh demokratis terhadap pencegahan bahaya narkoba. Penelitian menggunakan desain quasy experiment dengan two group pre and post test design, dengan tehnik sampling menggunakan purposive sampling. Penelitian dengan tahapan: (1) memilih pelatihan pola asuh tentang bahaya narkoba dengan kerangka teori $B=f(P F, E F, R F)$ yaitu faktor (predisposing factors, enabling factors, reinforcing factors), (2) melakukan pelatihan pola asuh demokratis pada orangtua, dan (3) impelementasi pola asuh demokratis orangtua tentang bahaya narkoba kepada remaja. Pengambilan data dengan kuesioner terhadap pengetahuan, sikap dan komitmen perilaku bebas narkoba bagi remaja sebelum dan sesudah pelatihan dan dibandingkan dengan group kontrol. Analisis Anova dari aspek pengetahuan, sikap dan komitmen perilaku responden pada group eksperimen dan kontrol menunjukkan nilai sig. 0,000<0,05 maka $\mathrm{H}_{1}$ diterima yaitu ada perbedaan yang signifikan antara group eksperimen dengan group kontrol. Kesimpulan pelatihan pola asuh demokratis orangtua efektive meningkatkan pengetahuan, sikap, dan komitmen perilaku hidup bebas narkoba bagi remaja.
\end{abstract}

Kata kunci : bahaya narkoba, bebas, pengetahuan, sikap

\begin{abstract}
Illicit trafficking and drug abuse have entered all levels of society, even among teenagers, this condition is very concerning and requires serious and sustainable prevention efforts. This study aims to examine the effectiveness of democratic parenting training on the prevention of the dangers of drugs. The study used a quasi-experimental design with two group pre and post-test designs, with a sampling technique using purposive sampling. Research with stages: (1) choosing parenting training about the dangers of drugs with a theoretical framework $B=f(P F, E F, R F)$ namely factors (predisposing factors, enabling factors, reinforcing factors), (2) conducting democratic parenting training for parents, and (3) the implementation of democratic parenting of parents about the dangers of drugs to adolescents. Collecting data with a questionnaire on knowledge, attitudes and commitment to drug-free behavior for adolescents before and after training and compared with the control group. Anova analysis of the aspects of knowledge, attitudes and behavioral commitment of respondents in the experimental and control groups showed the value of sig. $0.000<0.05$ then $\mathrm{HI}$ is accepted, that is, there is a significant difference between the experimental group and the control group. The conclusion is that democratic parenting training for parents is effective in increasing knowledge, attitudes, and commitment to drug-free behavior for adolescents.
\end{abstract}

Keywords: danger of drugs, free, knowledge, attitude

\section{PENDAHULUAN}

Bahaya narkoba mempengaruhi syaraf pusat kesadaran, hilangnya kendali, halusinasi, gelisah, depresi, perilaku kekerasan, kecanduan, gangguan mental dan kerusakan organ tubuh berujung kematian, serta bisa berdampak juga pada ekonomi, sosial budaya, hankam, dan kwalitas perilaku remaja sebagai harapan 
bangsa (Potter JS, 2015). Perilaku remaja yang tampak dalam penyalahgunaan narkoba sangat dipengaruhi oleh pola asuh orangtua, seperti yang ditunjukkan dalam penelitian analisis korelasi oleh (Budang, 2014) bahwa pola asuh permisif memiliki korelasi dengan remaja yang mempergunakan narkoba (Masni, 2017). Selain pola asuh permisif ada pola asuh lain yaitu pola asuh otoriter orang tua memiliki hubungan dengan remaja dalam menyalahgunakan narkoba (Sudarto, 2020). Penelitian komparasi pola asuh orangtua terbukti menunjukkan adanya perbedaan layanan sosial yang berkaitan dengan pola asuh demokratis, otoriter, atau permisif kepada kelompok remaja pengguna narkoba dalam pencegahan penyalahgunaan narkoba (Masni, 2017). Pola asuh demokratis orangtua memberikan layanan sosial dengan baik, ini merupakan penyebab remaja tidak menyalahgunakan narkoba.

Berdasarkan hasil penelitian yang sudah dilakukan, pola asuh demokratis diharapkan bisa menjadi pencegah bagi remaja supaya tidak terjerumus pada penyalahgunaan narkoba. Namun demikian ada masalah dengan pelaksanaannya karena melibatkan kelompok dan kurangnya pengetahuan serta ketrampilan orangtua tentang pola asuh demokratis (Hadriansyah, 2014). Untuk itu perlu dilakukan pelatihan pola asuh demokratis. Pengetahuan dan ketrampilan yang baik akan membentuk sikap yang baik dalam menerapkan pola asuh demokratis kepada remaja sehingga memperkuat komitmen perilaku hidup bebas narkoba. Pelatihan pola asuh demokratis dapat digunakan dan dipilih sebagai upaya alternatif untuk mencegah remaja agar tidak terjerumus dalam penyalahgunaan nakoba.

Tujuan penelitian ini adalah untuk mengetahui efektivitas pengaruh tentang pelatihan manajemen edukasi pola asuh demokratis orangtua tentang bahaya narkoba terhadap pengetahuan, sikap dan komitmen perilaku hidup bebas narkoba bagi remaja di SMK Nurus Sahid Probolinggo.

\section{METODE PENELITIAN}

Penelitian ini dilakukan 17 Maret 2021 - 16 Mei 2021 dengan menggunakan desain quasy experiment dengan pendekatan metode two-group pre-post test $t$ design. Responden dites sebelum diberi intervensi, dan dites lagi seudah intervensi dengan rancangan time series, dalam penelitian ini post test dilakukan oleh peneliti secara berulang dalam waktu tertentu yang ditentukan oleh peneliti (Nursalam, 2014).

Populasi dalam penelitian ini adalah seluruh siswa SMK Nurus Sahid Pobolinggo mulai kelas X, XI dan XII yang masih aktif berjumlah 102 orang. Pemilihan pepulasi sebagai sasaran penelitian dikarenakan lingkungan berada pada daerah resiko / rawan terhadap penyalahgunaan narkoba.

Sampling penelitian dilakukan dengan teknik purposive sampling. Sampel pada penelitan untuk group intervensi ditentukan 30 remaja dan group kontrol juga 30 remaja.

Kriteria Inklusi dalam penelitian ini adalah remaja sebagai siswa, usia $15-18$ tahun, berstatus aktif, tinggal serumah dengan orangtua, tidak merokok, tidak menggunakan narkoba, bersedia menjadi sampel dalam penelitian dan dalam kondisi sehat. Kriteria eklusi dari penelitian ini adalah siswa yang masuk dalam kelompok inklusi, apabila dalam proses penelitian siswa mengalami hambatan tidak bisa melanjutkan sebagai responden, seperti mengalami sakit, pindah sekolah, siswa yang mendapatkan peringatan dari sekolah atau siswa yang mendapatkan tugas dari sekolah.

Variabel independen dalam penelitian ini adalah pelatihan pola asuh demokratis orangtua tentang bahaya narkoba dan variabel dependen adalah pengetahuan, sikap, dan perilaku hidup bebas narkoba. Data dikumpulkan dengan kuesioner yang telah melalui uji Validitas (expert judgement), Pemahaman Bahasa dan Realibilitas (nilai Cronbach alfa 0,977). Instrumen berisi pernyataan dan jawaban dalam bentuk skala likert dengan mangacu pada unsur pernyataan favorable dan unfavourable, supaya tidak bias. Penelitian ini sudah ada persetujuan etik dari 
Komite Etik STIKes Hafshawaty Probolinggo dengan nomor: KEPK/002/STIKes-HPZH/III/2021.

Data yang dikumpulkan dari variabel dependen berupa data pengetahuan, sikap dan komitmen perilaku hidup bebas narkoba dengan periode pengambilan data sebelum dan sesudah edukasi. Analisis data hasil penelitian melalui editing, coding, scoring, tabulating, cleaning, tes normalitas, tes varians, dan uji hipotesis dengan Paired T-test untuk membandingkan nilai pre dan post test, sedangkan uji Anova untuk membandingkan nilai data rata-rata group perlakuan dengan kontrol.

\section{HASIL DAN PEMBAHASAN}

Berikut ini disajikan data dan pembahasan hasil penelitian tentang pelatihan pola asuh demokratis orangtua terhadap pengetahuan, sikap dan komitmen perilaku hidup bebas narkoba bagi remaja dengan mengukur tingkat pengetahuan, sikap, dan komitmen perilaku hidup bebas narkoba bagi remaja sebelum dan sesudah dilakukan pelatihan.

\section{Karakteristik Responden tentang Pola Asuh Orangtua di SMK Nurus Sahid}

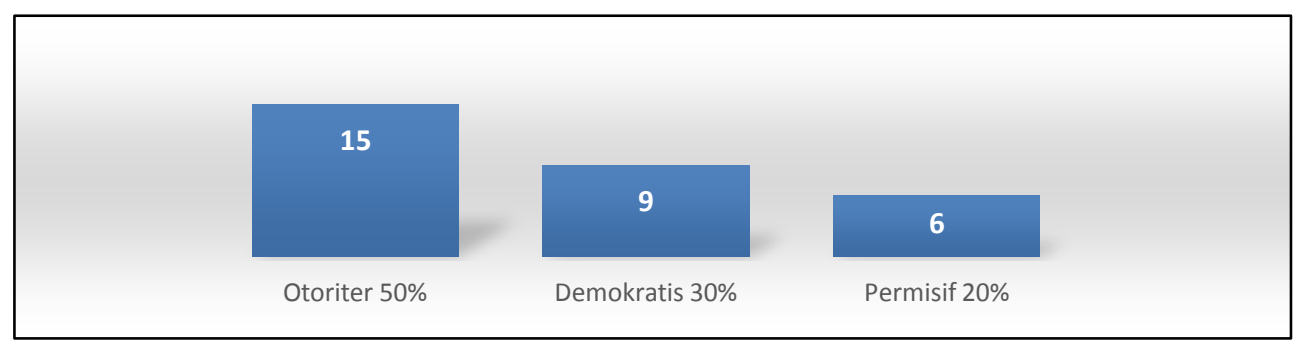

Gambar 1. Distribusi Frekuensi dan Persentase Pola Asuh Orangtua

Gambar 1 tersebut merupakan hasil survei yang menunjukkan bahwa dari 30 remaja bersama 30 orangtuanya dengan pola asuh otoriter sebanyak 15 orang (50\%). Ciri khas pola asuh otoriter adalah anak harus mengikuti perintah orang tua, anak tidak diberi kesempatan berdiskusi ataupun menyampaikan pendapat, orang tua memberikan hukuman bila anak salah, dan orang tua menggunakan suara keras bila berbicara dengan anak (Sumilah, 2017). Anak bisa jadi tidak bebas, hidup terkekang dan tidak percaya diri dengan pola asuh otoriter, sehingga anak mencari kebebasan di luar rumah sampai ke arah narkoba. Sedangkan ciri khas pola asuh permisif adalah anak diberi kebebasan yang luas, tidak ada kontrol dari orangtua dan sedikit sikap tegas jika anak berbuat salah. Anak dianggap seperti orang dewasa yang tidak perlu diawasi dan diarahkan. Pada anak dengan pola asuh demokratis ada pengawasan yang terkontrol dan kontinyu, bila anak berbuat salah ada hukuman yang terukur dan mendidik, ada kesempatan diskusi, perhatian menumbuhkan kasih sayang serta mandiri, orientasinya berprestasi, senang situasi baru, persahabatan dan menangani stres dengan baik (Budang, 2014).

\section{Nilai Rata-Rata Pre Test Tingkat Pengetahuan, Sikap, dan Perilaku Responden}

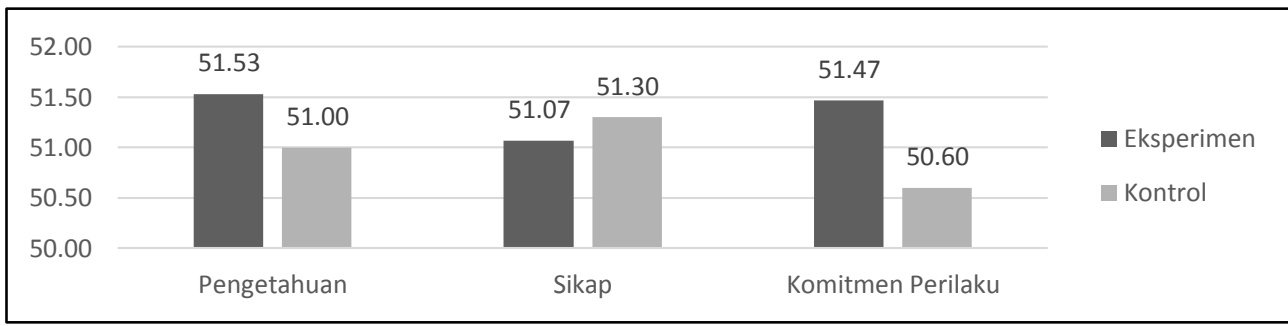

Gambar 2. Nilai Rata-Rata Pre Test Group Eksperimen dan Kontrol SMK Nurus Sahid Probolinggo 
Pada gambar 2 data nilai rata-rata Pre tes pada group eksprimen dan group kontrol dari aspek pengetahuan, aspek sikap dan aspek komitmen perilaku hidup bebas narkoba menunjukkan hasil nilai data yang mirip sebelum dilakukan pelatihan dari semua aspek tersebut. Uji independent samples test dengan nilai sig. 0,599 dengan dasar keputusan bila nilai sig. > 0,05, maka kedua group memilki nilai data yang sama. Dengan kondisi adanya data pre tes yang sama berarti kedua group tersebut berada pada titik awal yang sama (Elfindri, 2016). Penelitian komparatif hasilnya akan lebih nampak bisa dibedakan bila antara group penelitian dan group kontrol berawal dengan titik yang sama. Pada kondisi awal yang sama dengan perlakuan yang bebeda maka bisa didapatkan hasil yang berbeda (Siregar, 2017). Ranah pengetahuan seseorang akan meningkat pengetahuannya bila yang bersangkutan dipaparkan pada pengetahuan yang sama. Peningkatan pengetahuan berpengaruh terhadap sikap dan selanjutnya akan memberikan efek kepada seseorang untuk mengambil sebuah keputusan dalam berperilaku.

\section{Uji Beda Pre tes dan Post test Pada Group Eksperimen Responden}

Berikut ini disajikan tabel hasil uji beda pre tes dan post tes pada group eksperimen responden.

Tabel 1. Uji T Paired Pada Aspek Pengetahuan, Sikap dan Perilaku Group Eksperimen

Paired Samples Test

\begin{tabular}{|c|c|c|c|c|c|c|}
\hline & \multicolumn{4}{|c|}{ Paired Differences } & \multirow[b]{3}{*}{$\mathrm{t}$} & \multirow{3}{*}{$\begin{array}{c}\text { Sig. } \\
\text { (2-tailed) }\end{array}$} \\
\hline & \multirow[b]{2}{*}{ Mean } & \multirow{2}{*}{$\begin{array}{c}\text { Std. } \\
\text { Deviation }\end{array}$} & \multicolumn{2}{|c|}{$\begin{array}{c}95 \% \text { Confidence } \\
\text { Interval of the } \\
\text { Difference }\end{array}$} & & \\
\hline & & & Lower & Upper & & \\
\hline $\begin{array}{c}\text { Pair } 1 \text { Pre_Test Pengetahuan - } \\
\text { Post_Test Pengetahuan }\end{array}$ & -9.20000 & 4.91584 & -11.03561 & -7.36439 & -10.251 & .000 \\
\hline $\begin{aligned} \text { Pair } 2 & \text { Pre_Test sikap - } \\
& \text { Post_Test Sikap }\end{aligned}$ & -9.26667 & 5.46420 & -11.30703 & -7.22630 & -9.289 & .000 \\
\hline $\begin{aligned} \text { Pair } 3 & \text { Pre_Test Komitmen Perilaku - } \\
& \text { Post_Test Komitmen Perilaku }\end{aligned}$ & -9.40000 & 4.76047 & -11.17759 & -7.62241 & -10.815 & .000 \\
\hline
\end{tabular}

Berdasarkan tabel 1 data penelitian menunjukkan adanya peningkatan pada aspek pengetahuan, sikap dan perilaku hidup bebas narkoba bagi remaja, berdasarkan jawaban remaja pada lembar kuesioner setelah pelatihan pola asuh demokratis orangtua. melalui paired $t$ test diketahui adanya perbedaan nilai pre-test dengan post test yang signifikan yaitu $(.000<0,05)$. Berarti hipotesis diterima dengan dasar keputusan bila nilai sig $<0,05 \mathrm{H}_{1}$ diterima. Melalui paired $t$ test ini bertujuan untuk memperkuat penjelasan data nilai hasil penelitian pada gambar 3 dan sekaligus menjawab hipotesis penelitian (Istyastono, 2012).

Penelitian efektivitas pengaruh pelatihan manajemen edukasi pola asuh demokratis orangtua terhadap tingkat pengetahuan, sikap, dan komitmen perilaku hidup bebas narkoba bagi remaja bisa terlihat adanya perbedaan nilai antara Pre tes dengan post test 1 , post test 2, dan post test 3 . Perubahan yang terjadi pada group eksperimen terhadap aspek pengetahuan, sikap, dan komitmen perilaku hidup bebas narkoba responden juga bisa dilihat pada tabel 1 hasil uji hipotesis yang menggunakan uji $\mathrm{T}$ berpasangan (Paired T-tes). 


\section{Data Nilai Rata-Rata Post test Group Eksperimen Dan Kontrol di SMK Nurus Sahid Probolinggo}

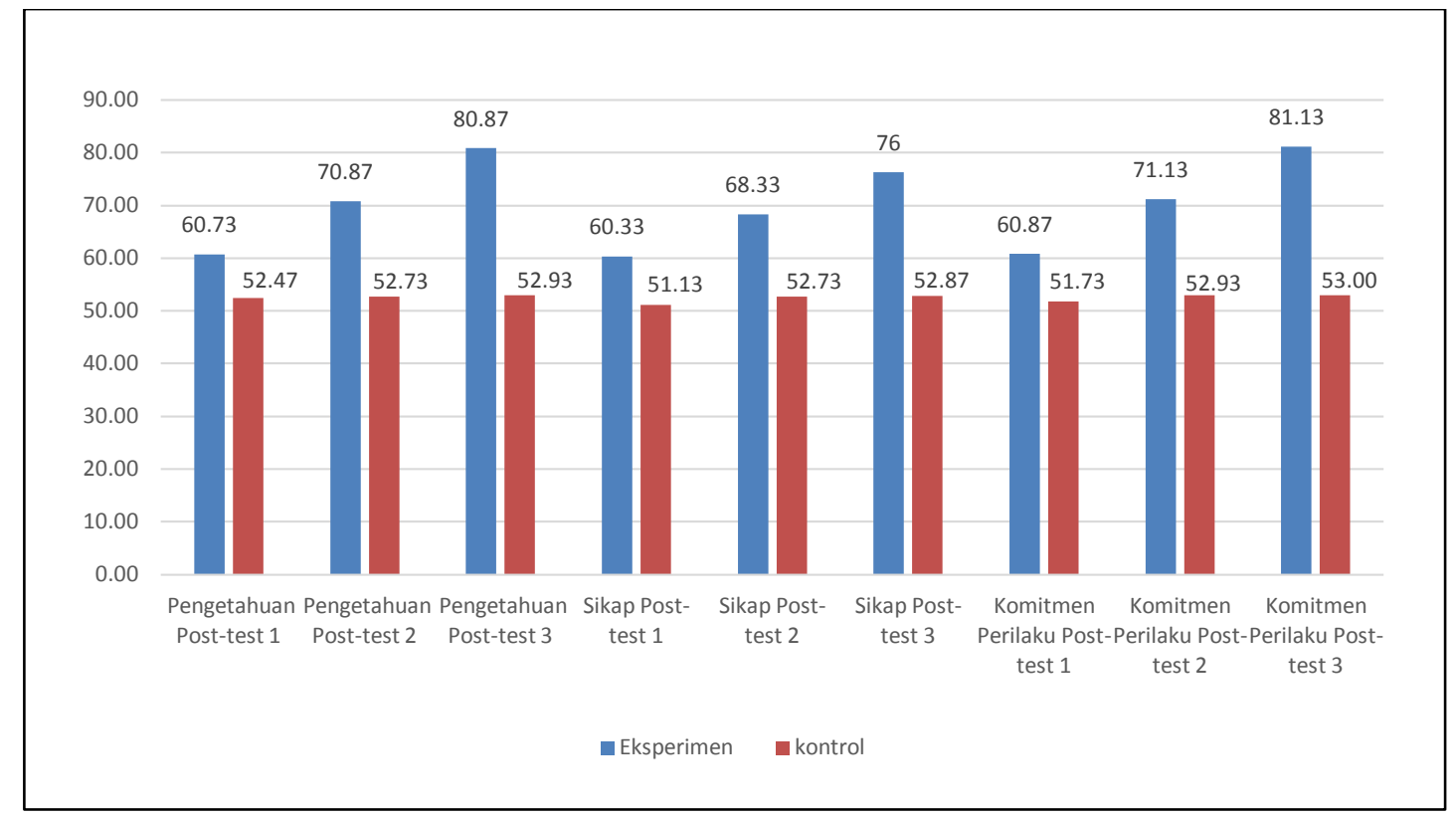

Gambar 3. Data Nilai Rata-Rata Post test Group Eksperimen Dan Kontrol

Pada gambar 3 data nilai rata-rata post test pada group eksprimen dan group kontrol menunjukkan hasil nilai yang sangat berbeda terutama post test 3 dan ini terjadi pada semua aspek yaitu aspek pengetahuan, aspek sikap, dan aspek komitmen perilaku hidup bebas narkoba bagi remaja. Dengan kondisi adanya data post test 3 atau post test akhir yang terpaut begitu jauh antara data nilai ratarata pada group eksperimen dengan group kontrol berarti kedua group tersebut mempunyai nilai titik akhir yang berbeda jauh atau dengan kata lain nampak nyata efektivitas dari pelatihan pelatihan pola asuh demokratis orangtua tentang bahaya narkoba terhadap pengetahuan, sikap dan komitmen perilaku hidup bebas naroba bagi remaja dengan demikian ini nantinya baik untuk diterapkan (Javadzadeh HA, 2015).

Studi komparatif tentang pola asuh otoriter, permisif dan demokratis terhadap upaya pencegahan penyalahgunaaan narkoba bagi remaja dengan hasil terbukti bahwa pola asuh demokratis lebih efektif dalam pencegahan penyalahgunaaan narkoba bagi remaja dibandingkan dengan pola asuh yang lain. Aspek komitmen perilaku group eksperimen mempunyai nilai puncak tertinggi yaitu 81,13 bila dibandingkan dengan nilai pada aspek lain pada group eksperimen dan group kontrol, kondisi ini terjadi oleh karena adanya efek dari aspek pengetahuan dan sikap karena pengambilan keputusan pada komitmen perilaku dipengaruhi oleh kondisi pengetahuan dan sikap seseorang (Dunn, 2018). Peningkatan tentang pengetahuan berpengaruh terhadap sikap dan selanjutnya akan memberikan efek kepada seseorang untuk mengambil sebuah keputusan dalam berperilaku.

Perbandingan Nilai Rata-Rata Post Test 1, 2, 3 Group Eksperimen dan Kontrol pada Responden di SMK Probolinggo

Berikut ini disajikan perbandingan nilai rata-rata post test $1,2,3$ group eksperimen dan kontrol pada responden di SMK Probolinggo. 
Grido Handoko Sriyono dkk., Pelatihan Pola Asuh Demokratis Orangtua terhadap Pengetahuan,

Sikap dan Perilaku Bebas Narkoba

Tabel 2. Hasil Uji LSD Anova Data Pengetahuan, Sikap dan Komitmen Perilaku Responden Post Test 1, 2, 3 Group Eksperimen dan Kontrol pada Remaja SMK Nurus Sahid Probolinggo

Multiple Comparisons

\begin{tabular}{|c|c|c|c|c|}
\hline (I) Post_Test_1,2,3 & (J) Post_Test_1,2,3 & $\begin{array}{c}\text { Mean } \\
\text { Difference } \\
\text { (I-J) }\end{array}$ & $\begin{array}{l}\text { Std. } \\
\text { Error }\end{array}$ & Sig. \\
\hline $\begin{array}{l}\text { Pengetahuan_Post_Test_1 Group } \\
\text { _Eksperimen }\end{array}$ & $\begin{array}{l}\text { Pengetahuan_Post_Test_1 Group } \\
\text { _Kontrol }\end{array}$ & $8.26667^{*}$ & 1.02945 & .000 \\
\hline $\begin{array}{l}\text { Pengetahuan_Post_Test_2 Group } \\
\text { _Eksperimen }\end{array}$ & $\begin{array}{l}\text { Pengetahuan_Post_Test_2 Group } \\
\text {_Kontrol }\end{array}$ & $18.13333^{*}$ & 1.02945 & .000 \\
\hline $\begin{array}{l}\text { Pengetahuan_Post_Test_3 Group } \\
\text { _Eksperimen }\end{array}$ & $\begin{array}{l}\text { Pengetahuan_Post_Test_3 Group } \\
\text {_Kontrol }\end{array}$ & $27.93333 *$ & 1.02945 & .000 \\
\hline $\begin{array}{l}\text { Sikap_Post_Test_1 Group } \\
\text { _Eksperimen }\end{array}$ & $\begin{array}{l}\text { Sikap_Post_Test_1 Group } \\
\text {_Kontrol }\end{array}$ & $9.20000 *$ & 1.02512 & .000 \\
\hline $\begin{array}{l}\text { Sikap_Post_Test_2 Group } \\
\text { _Eksperimen }\end{array}$ & $\begin{array}{l}\text { Sikap_Post_Test_2 Group } \\
\text { _Kontrol }\end{array}$ & $15.60000 *$ & 1.02512 & .000 \\
\hline $\begin{array}{l}\text { Sikap_Post_Test_3 Group } \\
\text { _Eksperimen }\end{array}$ & $\begin{array}{l}\text { Sikap_Post_Test_3 Group } \\
\text { _Kontrol }\end{array}$ & $23.46667 *$ & 1.02512 & .000 \\
\hline $\begin{array}{l}\text { Komitmen Perilaku_Post_Test_1 } \\
\text { Group _Eksperimen }\end{array}$ & $\begin{array}{l}\text { Komitmen Perilaku_Post_Test_1 } \\
\text { Group _Kontrol }\end{array}$ & $9.13333^{*}$ & .95615 & .000 \\
\hline $\begin{array}{l}\text { Komitmen Perilaku_Post_Test_2 } \\
\text { Group _Eksperimen }\end{array}$ & $\begin{array}{l}\text { Komitmen Perilaku_Post_Test_2 } \\
\text { Group _Kontrol }\end{array}$ & $18.20000^{*}$ & .95615 & .000 \\
\hline $\begin{array}{l}\text { Komitmen Perilaku_Post_Test_3 } \\
\text { Group _Eksperimen }\end{array}$ & $\begin{array}{l}\text { Komitmen Perilaku_Post_Test_3 } \\
\text { Group _Kontrol }\end{array}$ & $28.13333^{*}$ & .95615 & .000 \\
\hline
\end{tabular}

Berdasarkan tabel 2 hasil analisis variansi dengan uji Anova pada aspek pengetahuan, sikap dan perilaku responden pada group eksperimen dan group kontrol terlihat dari hasil perbandingan post test 1 , 2 dan 3 menunjukkan bahwa semua aspek dengan nilai sig. $0,000<0,05$ maka $\mathrm{H}_{1}$ diterima yang artinya keduanya memiliki pengetahuan, sikap dan komitmen perilaku yang berbeda. Maka dapat disimpulkan bahwa post test 1 , 2, dan 3 group eksperimen jauh lebih baik daripada group kontrol berarti ada perbedaan yang sangat signifikan.

\section{Pengetahuan}

Berikut disajikan hasil uji hipotesis (independent samples t-test) aspek pengetahuan responden post test 1 , post test 2 , dan post test 3 pada group eksperimen dan kontrol di SMK Nurus Sahid Probolinggo.

Tabel 3. Hasil uji Hipotesis (Independent Samples T-test) Aspek Pengetahuan Responden Post Test 1, Post Test 2, dan Post Test 3 Pada Group Eksperimen dan Kontrol di SMK Nurus Sahid Probolinggo

\begin{tabular}{ccc}
\hline Klasifikasi Data Aspek Pengetahuan & p-value & Keterangan \\
\hline Post test 1 group eksperimen dan kontrol & 0,00 & $\mathrm{H}_{1}$ diterima \\
Post test 2 group eksperimen dan kontrol & 0,00 & $\mathrm{H}_{1}$ diterima \\
Post test 3 group eksperimen dan kontrol & 0,00 & $\mathrm{H}_{1}$ diterima \\
\hline
\end{tabular}

Pada tabel 3 hasil uji beda dengan Independent Samples T-test pada aspek pengetahuan untuk post test 1 , post test 2 , dan post test 3, menunjukkan adanya perbedaan yang sangat signifikan antara group eksperimen dengan group kontrol. 
Hal ini terjadi karena group eksperimen memiliki pengetahuan semakin baik setelah dilakukan pelatihan manajemen edukasi pola asuh demokratis orangtua, hal itu terlihat dari hasil perbandingan data nilai pre tes dengan data nilai post test 1 , post test 2 dan post test 3 , pada group eksperimen dibandingkan dengan group kontrol yang bisa dilihat pada gambar 3. Hal tersebut juga dapat membuktikan bahwa pelatihan manajemen edukasi pola asuh demokratis orangtua terhadap tingkat pengetahuan bagi remaja yang dilaksanakn terbukti efektif bisa menambah tingkat pengetahuan remaja tentang bahaya narkoba.

Pengetahuan remaja yang bertambah tersebut sesuai dengan pernyataan dari Notoatmodjo (2012) menyebutkan bahwa bertambahnya pengetahuan terjadi karena seseorang ada perilaku ingin tahu yang dilanjutkan dengan proses penginderaan (Lestari, 2014). Pada penjelasan tersebut bisa dipertegas peningkatan pengetahuan terjadi oleh sebab dari pada hasil keingintahuan responden setelah adanya peninderaan pada pelatihan (Budiarnawan, 2015). Selain itu bahwa pelatihan pola asuh demokratis orangtua terhadap tingkat pengetahuan bahaya narkoba bagi remaja adalah salah satu cara untuk membentuk kemandirian remaja pada peningkatan pemahaman informasi kearah terbentuknya komitmen sikap.

\section{Sikap}

Berikut ini disajikan hasil uji hipotesis (independent samples t-test) aspek sikap responden post test 1 , post test 2 , dan post test 3 pada group eksperimen dan kontrol di SMK Nurus Sahid Probolinggo.

Tabel 4. Hasil uji Hipotesis (Independent Samples T-test) Aspek Sikap Responden Post Test 1, Post Test 2, dan Post Test 3 Pada Group Eksperimen dan Kontrol di SMK Nurus Sahid Probolinggo

\begin{tabular}{ccc}
\hline Klasifikasi Data Aspek Sikap & p-value & Keterangan \\
\hline Post test 1 group eksperimen dan kontrol & 0,00 & $\mathrm{H}_{1}$ diterima \\
Post test 2 group eksperimen dan kontrol & 0,00 & $\mathrm{H}_{1}$ diterima \\
Post test 3 group eksperimen dan kontrol & 0,00 & $\mathrm{H}_{1}$ diterima \\
\hline
\end{tabular}

Pada tabel 4 hasil uji Independent Samples T-test pada aspek sikap untuk post test 1 , post test 2, dan post test 3, menunjukkan adanya berbedaan yang sangat signifikan antara group eksperimen dengan group kontrol. Perbedaan aspek sikap ini terjadi oleh karena adanya peningkatan sikap responden group eksperimen sampai dengan kategori baik yang bisa dilihat pada gambar 3 , terjadinya peningkatan pada post test 1,2 , dan 3 dimungkinkan oleh adanya faktor lain juga, seperti perubahan sikap terjadi oleh karena kondisi seseorang yang berubah. Tetapi dalam penelitian ini perubahan peningkatan sikap yang lebih baik pada remaja bisa terjadi karena disebabkan adanya peningkatan pengetahuan dari pelatihan manajemen edukasi pola asuh demokratis orangtua terhadap tingkat pengetahuan, sikap, dan komitmen perilaku hidup bebas narkoba bagi remaja.
Berarti pelatihan manajemen edukasi pola asuh demokratis orangtua telah terbukti efektif bisa meningkatkan sikap responden terhadap komitmen perilaku hidup bebas narkoba pada group eksperimen dibandingkan group kontrol yang tidak mendapatkan pelatihan. Selain itu juga ada faktor lain yang juga bisa berpengaruh terhadap perubahan sikap yaitu media informasi dari berbagai media berita, media sosial, budaya dan lingkungan (Anggraini, 2014). Sikap positif responden ini perlu dipelihara secara kontinyu untuk mendukung menuju sikap komitmen perilaku hidup bebas narkoba yang lebih mantab (Anwar, 2013).

\section{Perilaku}

Berikut ini disajikan hasil uji hipotesis (independent samples t-test) aspek komitmen perilaku responden post test 1 , post test 2 , dan post test 3 pada group eksperimen dan kontrol di SMK Nurus Sahid Probolinggo. 
Tabel 5. Hasil uji Hipotesis (Independent Samples T-test) Aspek Komitmen Perilaku Responden Post Test 1, Post Test 2, dan Post Test 3 pada Group Eksperimen dan Kontrol di SMK Nurus Sahid Probolinggo

\begin{tabular}{ccc}
\hline Klasifikasi Data Aspek Komitmen Perilaku & p-value & Keterangan \\
\hline Post test 1 group eksperimen \& Kontrol & 0,00 & $\mathrm{H}_{1}$ diterima \\
Post test 2 group eksperimen \& Kontrol & 0,00 & $\mathrm{H}_{1}$ diterima \\
Post test 3 group eksperimen \& Kontrol & 0,00 & $\mathrm{H}_{1}$ diterima \\
\hline
\end{tabular}

Pada tabel 5 hasil uji Independent Samples T-test pada aspek komitmen perilaku untuk post test 1 , post test 2 , dan post test 3 , menunjukkan adanya berbedaan yang sangat signifikan antara group eksperimen dengan group kontrol. Hal ini terjadi karena adanya peningkatan komitmen perilaku dengan kategori baik yang bisa dilihat pada gambar 3 dari hasil post test 3 pada group eksperimen dibandingkan dengan group kontrol ada perbedaan yang sangat signifikan. Peningkatan komitmen perilaku remaja bisa timbul diantaranya disebabkan oleh adanya aspek pengetahuan dan sikap baik yang bisa menjadi motivator atau pendorong responden untuk melakukan suatu komitmen perilaku (Sweeney CT, 2015).

Terjadinya peningkatan komitmen perilaku responden tersebut lebih bisa membuktikan bahwa pelatihan manajemen edukasi pola asuh demokratis orangtua efektif dalam meningkatkan komitmen perilaku group eksperimen bila dibandingkan dengan group kontrol (Wu LT, 2013). Berikut dipaparkan perbandingan data nilai rata-rata responden berdasarkan aspek komitmen perilaku setelah dilakukan pelatihan manajemen edukasi pola asuh demokratis orangtua, di tahap post test 3 pada group eksperimen 81,13 dengan group kontrol 53,00.

\section{KESIMPULAN DAN SARAN}

Pola asuh Remaja di SMK Nurus Sahid Probolinggo sebagian dengan pola asuh otoriter 15 responden $(50 \%)$ dari 30 responden. Data nilai rata-rata Pre test dari kedua group mendekati titik awal yang sama, sedangkan data nilai rata-rata post test dari kedua group dengan kategori yang sangat jauh berbeda. Group eksperimen setelah mendapatkan pelatihan manajemen edukasi pola asuh demokratis orangtua nilai rata-ratanya melaju naik terus sampai mendapatkan nilai puncak baik pada post test 3, yaitu 81,13 sedangkan group kontrol 53,00 . Pelatihan pola asuh demokratis orangtua efektif meningkatkan pengetahuan, sikap, dan komitmen perilaku hidup bebas narkoba bagi remaja.

Saran bagi pPenelitian berikutnya agar bisa menambah waktu penelitian atau frekuensi post testnya sehingga bisa diketahui berapa lama pemahaman responden untuk tahu dan bersikap mempertahankan komitmen perilaku untuk hidup bebas narkoba setelah waktu pelatihan tersebut.

\section{REFERENSI}

Anggraini, (2014). Hubungan pola asuh Orangtua dengan motivasi belajar remaja. Jurnal Ilmiah Pendidikan Bimbingan dan Konseling., 2(1), p. 76-90 .

Anwar, (2013). Hubungan Tingkat Pengetahuan, Program Terapi Metadon Dengan Tingkat Motivasi Mengikuti Program Terapi Rumatan Metadon Pada Pengguna Narkoba Suntik Di Puskesmas Kecamatan Grogol Petamburan Jakarta Barat. Jurnal tingkat pengetahuan, 3(4), pp. 127-140.

Budang, P. W. N. \&. F. (2014). Korelasi pola asuh Orangtua dengan hasil belajar. J Pendidik Dasar PerKhasa, 4(2), pp. 49-66. .

Budiarnawan, K. A. A. N. N. M. \&. R. N. (2015). Hubungan antara konsep diri dan pola asuh Orangtua terhadap hasil belajar IPA Remaja. J Mimb PGSD Univ Pendidik, 2(1), pp. 1322. 
Dunn, H. K. P. D. N. B. A. \&. F. P. (2018). Psychosocial Determinants of Teens' Online Engagement in Drug Prevention Social Media Campaigns. J Prim Prev, 3(5), p. 69-81.

Elfindri, H. H. A. M. R. (2016). Metode Penelitian Kesehatan.Media. 1 ed. jakarta: Medika.

Hadriansyah, (2014). Pengetahuan Dan Sikap Keluarga Dalam Upaya Pencegahan. J Ilm Dikdaya., 6(2), pp. 149-202.

Javadzadeh HA, M. F. R. M. M. B. N. (2015). The relationship between knowledge and practice regarding the application of health literacy strategies in patient edukation. $J$ Mil Care Sci., 2(1), p. 33-40. .

Lestari, (2014). Hubungan Pengetahuan, Sikap Remaja dan Pekerjaan Orangtua tentang Narkoba pada Remaja SMA Negeri 1 Takalar.. $J$ Ilm Kesehat Diagnosis., 5(2), pp. 117-122..

Masni, H. (2017). Peran Pola Asuh Demokratis Orangtua Terhadap Pengembangan. J Ilm Dikdaya, 6(1), p. 58-74. .

Potter JS, M. E. H. M. N. S. W. K. C. C. L. (2015). Buprenorphine/naloxone and methadone maintenance treatment outcomes for opioid. . J Stud Alcohol Drugs, 2(1), p. 605-613.

Siregar, (2017). Statistika Parametrik untuk Penelitian Kuantitatif. 2 ed. Jakarta: PT. Bumi Aksara.

Sudarto, (2020). Pola Asuh Orangtua dalam Pengembengan Potensi Diri dan Karakter. J Ilm Ilmu Pendidik Persada Khatulistiwa Sintang., 11(1), p. $26-38$.

Sumilah, A. N. (2017). Pengaruh Pola Asuh Orangtua Terhadap Hasil Belajar. $J$ Kreat Kependidikan Dasar., 7(2), pp. 189-199..

Sweeney CT, S. M. E. M. S. S. S. (2015). Nonmedical use of prescription ADHD stimulants and preexisting patterns of drug abuse.. J Addict Dis. , 3(2), pp. 23-34.

Wu LT, W. G. Y. C. B., (2013). How do prescription opioid users differ from users of heroin or other drugs in psychopathology: results from the National Epidemiologic Survey on Alcohol and Related Conditions. $J$ Addict Med, 3(4), pp. 110-122. 